\title{
A survey of Maori potato (taewa) seed tubers for the presence of Candidatus Liberibacter solanacearum
}

\author{
A.J. Puketapu ${ }^{1}$, R. Gardner-Gee ${ }^{1}$, L.K. Tooman ${ }^{1}$ and S.S. Beard ${ }^{2}$ \\ ${ }^{1}$ The New Zealand Institute for Plant E Food Research Limited, Mt Albert Research \\ Centre, 120 Mt Albert Rd, Sandringham, Auckland 1025 \\ ${ }^{2}$ The New Zealand Institute for Plant E Food Research Limited, Private Bag 4704, \\ Christchurch 8140, New Zealand \\ Correspondingauthor: Aleise.puketapu@plantandfood.co.nz
}

\begin{abstract}
Taewa (Solanum tuberosum L.) production is threatened by a new insect pest, the tomato potato psyllid (Bactericera cockerelli Sulc.), and the bacterium (Candidatus Liberibacter solanacearum (Lso)) vectored by the psyllid. Lso is known to reduce potato yields and can infect seed tubers, but less is known for taewa specifically. In this study tubers from 17 taewa lines were tested for Lso using a qPCR assay, grown in a greenhouse and assessed for symptoms of tuber-borne Lso. Lso was detected by qPCR in three tubers. The Lso-positive tubers were from three lines from two North Island seed sources; no Lso was detected in the seven South Island lines tested. In the greenhouse trial, two of the three Lso-positive tubers emerged and one grew normally. The greenhouse trial detected disease symptoms associated with Lso in several other lines, but other potato viruses and diseases cause similar symptoms, and this area needs further study.
\end{abstract}

Keywords tomato-potato psyllid, zebra chip, seed tuber, potato, TPP.

\section{INTRODUCTION}

The potato was first introduced to New Zealand in 1769 , by early explorers such as Surville, Cook and du Frense (Harris \& Niha 1999). Historic records show that, during the contact and colonisation periods, potatoes were brought to New Zealand from Holland, South Africa, South America, Mexico and Western Europe (Harris \& Niha 1999). Early Maori adopted the practice of growing potatoes and quickly recognised the crop was hardy and less physically demanding than kumara (Ipomoea batatas (L.) Lam) (Cameron 1964; Roskruge 1999). Taewa eventually replaced crops like kumara (I. batatas (L.) Lam) and aruhe (Dicksonia squarrosa (G. Forst) Sw.; bracken fern rhizome) as the main source of carbohydrate in the early Maori diet (Roskruge 2007). Potatoes cultivated by Maori during this time were (and still are) commonly referred to as taewa, peruperu and parareka. By 1840 Maori considered the potato as a staple food (Roskruge 1999). Cropping in the $21^{\text {st }}$ century is limited to Maori families and non-Maori enthusiasts who maintain cultivar collections. Seed tuber collections are maintained by the New Zealand Institute for Plant \& Food Research (PFR) for study and breeding purposes. Tahuri Whenua 
Incorporated Society (TWIS, the National Maori Vegetable Growers Collective) along with the Institute of Agriculture and Environment at Massey University also maintains a collection in order to preserve and repatriate taewa back to marae (ancestral meeting house), iwi (tribe) and hapu (sub tribe). The Koanga Institute perpetuates heritage potato lines (including many taewa varieties) in collections maintained in Northland and more recently, in Hawke's Bay. In recent years annual infestations of taewa by the tomato-potato psyllid (TPP) (Bactericera cockerelli Sulc. (Hemiptera: Triozidae)), have threatened taewa crops. TPP vectors Candidatus Liberibacter solanacearum (Lso), the causal agent of zebra chip (ZC) disease in affected potato crops. In potatoes, the above-ground symptoms of ZC infection include leaf curl, leaf discolouration, swollen internodes, aerial tubers, stunting and premature death. Tuber symptoms include darkening of the medullary rays. TPP was first detected in New Zealand in 2006 and the 2008/2009 cropping season was the first time TPP was seen in taewa crops. Infestations in taewa were reported throughout New Zealand that season including Palmerston North, Gisborne and Christchurch, where heavy feeding damage and potential Lso infection caused early plant death and reduced yields (N.R. Roskruge, Massey University, personal communication). Commercial potatoes have been similarly affected and growers have increased agrichemical applications to ensure marketable yields are achieved. Taewa growers are limited in terms of insect control methods as many follow traditional Maori growing practices, where synthetic chemical inputs are not accepted.

As well as reducing crop yields, the TPP/Lso complex has the potential to negatively affect seed tuber performance. Henne et al. (2010) showed that potato crops grown from Lso-positive seed tubers had only a $20-40 \%$ sprouting rate. Low seed and shoot vigour, delayed emergence, and plant death after only a few weeks of growing were also observed. These effects, coupled with reduced yields, could threaten taewa production in New Zealand. Potential reductions in seed tuber quality and vigour are major concerns raised by taewa growers, especially regarding some of the rarer or relic varieties (N.R. Roskruge, Massey University, personal communication). Despite these concerns, there has been no previous survey of Lso incidence in taewa. The objectives of this study were to conduct a survey of 20 taewa lines for the presence of Lso (Candidatus Liberibacter solanacearum) and to assess tuber emergence and early plant growth in response to potential Lso infection.

\section{MATERIALS AND METHODS \\ Collection of potato samples}

Taewa samples were sourced from three growers: Massey University/TWIS tubers produced in Manawatu, North Island) (NI), PFR (tubers produced in Lincoln, South Island) (SI), and Koanga Institute (tubers produced in Hokianga, North Island) (K). In total, 20 lines were tested for Lso using the qPCR assay described below. Seventeen lines were included in the greenhouse study. Table 1 shows the 20 taewa varieties used in the study.

\section{Tuber preparation}

Tubers were stored at $5 \pm 1{ }^{\circ} \mathrm{C}$ on arrival at two PFR sites, Mt Albert Research Centre and Pukekohe Research Centre, until required. Ten individual tubers from each taewa line were used for both genetic analysis and the greenhouse study. Three weeks prior to planting, a $10-15 \mathrm{~mm}$ slice was removed from the stolon end of each tuber. The slices were labelled and frozen for later Lso testing using quantitative PCR (qPCR) diagnostic tests. The remainder of the tuber was used as a seed piece for the greenhouse study. On cutting, an assessment of the raw material was made for symptoms of Lso based on discolouration of the vascular ring; assessments were made on a 1-5 scale developed by John Anderson at PFR Pukekohe for assessing raw ZC symptoms. A raw score of ' 1 ' indicated no discolouration and a score of ' 5 ' indicated severe discolouration (Anderson et al. 2012).

Seed pieces were stored at approximately $20^{\circ} \mathrm{C}$ for 3 weeks (Henne et al. 2010) to suberise and 
Table 1 Taewa (Solanum tuberosum L.) lines surveyed for Lso (Candidatus Liberibacter solanacearum) infection. Italicised lines were not included in the greenhouse study due to poor $(<20 \%)$ tuber sprouting.

\begin{tabular}{lll}
\hline Massey University (NI) & PFR, Lincoln (SI) & Koanga Gardens (K) \\
\hline 'Waiporoporo' & 'Poiwa' & 'Paraketia' \\
'Kowiniwini' & 'Te Maori' & 'Whataroa' \\
'Karuparera' & 'Ngaoutiouti' & 'Maori' \\
'Maori Chief' & 'Huakaroro' & 'Karoro' (syn. 'Huakaroro') \\
'Te Maori' & 'Maori Chief' & 'Urenika' \\
'Kohatuwhero' & 'Blue Derwent' ('Kopara, 'Katote') & 'Matariki' \\
'Urenika' & & 'Kowiniwini' \\
\hline
\end{tabular}

sprout. Only sprouted tubers were used for the greenhouse study. Three lines ('Urenika' (NI), 'Kohatuwhero' (NI) and 'Kowiniwini' (K)) had poor sprouting (less than 20\%) and were not included in the greenhouse study. These lines were excluded from the study to remove seed viability as a possible cause of non-emergence.

\section{Greenhouse study}

Ten sprouted seed pieces per line were planted in PB5 black plastic planter bags with potting mix (Daltons $^{\mathrm{TM}}$ Premium Potting Mix) and kept in a greenhouse at Pukekohe Research Centre for the duration of the trial. Drip irrigation was set to water the bags daily for $1 \mathrm{~min}$, increasing to $3 \mathrm{~min}$ at 2 weeks after planting to prevent seed piece decay.

Weekly growing assessments were made every 7 days beginning 7 days after planting (DAP) and continuing up until 56 DAP (Henne et al. 2010). Quantitative measurements included: plant emergence and survival, number of shoots/ stems and shoot height. Basal stem diameter was also measured using a digital calliper (Henne et al. 2010). Visual assessments of leaf and stem discolouration were also undertaken. Plant growth habit was assessed in the first 3 weeks of the study and divided into three categories: normal, hair sprout (HS) and witches broom (WB). HS plants are characterised by thin stems that are generally $2 \mathrm{~mm}$ in diameter from sprouting through the duration of plant growth (Harvey et al. 1944). HS stems are weak and can reach $6-8 \mathrm{ft}$ (183-244 cm) in length (Harvey et al. 1944). WB is a potato disease caused by phytoplasma; infected plants initially show upward rolling and chlorosis of the leaflets, advancing to dwarfed plants with many fine stems (Wright 1954). Expression of HS- and WB-like symptoms have been reported in Lso-positive potato plants grown from infected tubers (Henne et al. 2010; Pitman et al. 2011). For the purposes of analysis, $\mathrm{HS}$ and WB plants were pooled into the category 'abnormal emergence'.

\section{Quantitative PCR (qPCR) diagnostic tests for Lso} Approximately $100 \mathrm{mg}$ of tissue was taken from the vascular ring of each tuber slice. Samples were prepared manually by lysing tissue, adding $400 \mu \mathrm{l}$ buffer per sample (consisting of $4 \mu \mathrm{l}$ DX and $396 \mu \mathrm{l}$ DXT solutions, both supplied by Qiagen Ltd) and then incubating samples overnight in a $55^{\circ} \mathrm{C}$ water bath. DNA was extracted using the QIAxtractor as per the manufacturer's instructions (Qiagen Ltd). For all samples, three subsamples were tested for a Lso-specific gene sequence (16S rRNA) and three subsamples were tested for EF1 $\alpha$ (a potato gene used as internal control, see Nicot et al. (2005) for details). Lso and EF1 $\alpha$ presence was determined using the single-step semi-nested Lso SYBR Green qPCR protocol developed by Beard et al. (2012). In brief, the qPCR for Lso was performed in $12 \mu \mathrm{l}$ reactions, each containing $2 \mu$ template, $50 \mathrm{nM}$ primer LsoF, $300 \mathrm{nM}$ of primer Lso $16 \mathrm{SF}$ and $300 \mathrm{nM}$ of the primer Lso 16SRI (see Beard et al. 2012) for primer details). The qPCR for EF1 $\alpha$ was also performed in $12 \mu \mathrm{l}$ reactions, each reaction containing $2 \mu$ template, 
$6 \mu \mathrm{l} \mathrm{SYBR}$ Green mastermix, $300 \mathrm{nM}$ of primer $\mathrm{EF} 1 \alpha \mathrm{F}$ and $300 \mathrm{nM}$ of the primer EF1 $\alpha \mathrm{R}$. Lso and $\mathrm{EF} 1 \alpha$ reactions for each set of samples were run simultaneously on the same qPCR well plate using a Roche 480 LightCycler ${ }^{\circledR}$ Platform (Roche Diagnostics). To monitor for contamination, negative controls and no-template controls (i.e. reactions with template from Lso-free tissueculture plants and reactions with no template respectively) were included on every well plate. The amplification parameters were: $96^{\circ} \mathrm{C}$ for $3 \mathrm{~min}$, followed by 45 amplification cycles of $96^{\circ} \mathrm{C}$ for $20 \mathrm{~s}, 60^{\circ} \mathrm{C}$ for $20 \mathrm{~s}$ and $72^{\circ} \mathrm{C}$ for $20 \mathrm{~s}$, with data capture at $72^{\circ} \mathrm{C}$. A melt curve followed $\left(95^{\circ} \mathrm{C}\right.$ for $5 \mathrm{~s}, 60^{\circ} \mathrm{C}$ for $1 \mathrm{~min}$ then $60^{\circ} \mathrm{C}$ to $90^{\circ} \mathrm{C}$ at $0.11^{\circ} \mathrm{C} / \mathrm{s}$ with continuous data acquisition). Gene quantities (i.e. number of copies of the target gene per well) were calculated from Cycle thresholds (Ct) and in-run standard curves using the 480 LightCycler ${ }^{\circledR}$ Platform software. Following Beard et al. (2012), a tuber was regarded as Lso positive if amplification (with expected melt curve) was observed in at least two of the three subsamples. This conservative approach was adopted to minimise the possibility of false-positive results, for although all results reported are from qPCR plates with no evidence of contamination in the controls, sporadic low-titre contamination was observed in other plates.

\section{Statistical analysis}

Percentages and mean values were calculated using Microsoft ${ }^{\circledR}$ Excel 2007. Low numbers of positive results precluded a formal statistical analysis. Graphs were generated using SigmaPlot 10.0.

\section{RESULTS}

\section{Vascular discolouration, plant emergence and Lso presence}

The qPCR testing did not detect Lso in the three lines of taewa that failed to sprout ('Kohatuwhero' (NI), 'Urenika' (NI) and 'Kowiniwini' (K)). The qPCR results for the 17 lines that were included in the greenhouse trial are given in Table 2. Lso was detected (in 2 or more of the sub-samples tested) in three tubers sourced from the North Island. Lso titre was low in all three tubers $(\mathrm{Ct}$ values ranged from 32-40, gene quantities ranged from 6-3070). An additional five tubers (all from North Island sources) had amplification in one of the sub-samples tested (Ct values were 40 each time). In all these cases, the amplified product had the melt-curve expected for Lso. No Lso was detected in any South Island lines. Two of the three Lso-positive tubers emerged and continued to grow for the duration of the monitoring period, but the third did not emerge. The Lso positive tuber in 'Waiporoporo' (NI) was the only tuber of the three to show any signs of $\mathrm{ZC}$ on cutting.

Table 2 shows Lso-like symptoms were not limited to Lso positive lines. Clear examples of this were seen in 'Huakaroro' (SI) where 90\% of tubers did not emerge and in 'Matariki' (K) and 'Te Maori' (NI) where $50 \%$ of each line displayed abnormal emergence. In addition eight lines in total showed distinct discolouration of the vascular ring (raw score $>2$ ), but only two of these lines were Lso positive. Only five lines, 'Poiwa' (SI), 'Te Maori' (SI), 'Maori Chief' (SI), 'Karuparera' (NI) and 'Paraketia' (K), did not show any disease or possible Lso symptoms from tuber cutting to plant emergence.

'Te Maori' (syn. 'Maori') and 'Maori Chief' were two lines that could be compared geographically in terms of seed source. 'Te Maori' seed was received from all three seed sources; the SI line was clear of any signs of Lso infection during sprouting and early emergence whereas the NI line scored 50\% abnormal emergence. The $\mathrm{K}$ line exhibited $10 \%$ non emergence and 20\% had raw scores $>2$. 'Maori Chief' (SI) showed no defects or Lso symptoms during sprouting and early emergence. One of the NI seed tubers tested positive for Lso and did not emerge. In general the 'Maori Chief' (NI) line did not perform well in this trial with $80 \%$ non emergence, $10 \%$ abnormal emergence and $20 \%$ of the raw tubers scoring above 2 for discolouration.

\section{Plant growth}

Overall there was no clear difference in growth patterns between lines that had positive qPCR results ('Waiporoporo' (NI), 'Maori Chief' (NI) and 'Urenika' $(\mathrm{K})$ ), lines that had pronounced symptoms of potential Lso infestation ('Huakaroro' 
Table 2 Tuber non-emergence and abnormal emergence rates, \% tubers with raw score $>2$ and Lso status determined by qPCR (number of Lso-positive tubers) for 17 taewa lines.

\begin{tabular}{lcccc}
\hline Taewa variety & $\begin{array}{c}\text { \% no } \\
\text { emergence }\end{array}$ & $\begin{array}{c}\text { \% abnormal } \\
\text { emergence }\end{array}$ & $\begin{array}{c}\text { \% tubers with } \\
\text { raw score }>2\end{array}$ & $\begin{array}{c}\text { number of LSO } \\
\text { +ve tubers }\end{array}$ \\
\hline 'Poiwa' (SI) & 0 & 0 & 0 & 0 \\
'Te Maori' (SI) & 0 & 0 & 0 & 0 \\
'Ngaoutiouti' (SI) & 0 & 20 & 10 & 0 \\
'Huakaroro' (SI) & 90 & 10 & 20 & 0 \\
'Maori Chief' (SI) & 0 & 0 & 0 & 0 \\
'Blue Derwent' (SI) & 20 & 10 & 0 & 0 \\
'Waiporoporo' (NI) & 10 & 0 & 30 & 1 \\
'Te Maori' (NI) & 0 & 50 & 0 & 0 \\
'Kowiniwini' (NI) & 0 & 20 & 10 & 0 \\
'Karuparera' (NI) & 0 & 0 & 0 & 0 \\
'Maori Chief' (NI) & 80 & 10 & 20 & 0 \\
'Paraketia' (K) & 0 & 0 & 0 & 0 \\
'Whataroa' (K) & 0 & 30 & 0 & 0 \\
'Maori' (K) & 10 & 0 & 20 & 1 \\
'Urenika' (K) & 10 & 10 & 0 & 0 \\
'Matariki' (K) & 30 & 50 & 10 & 0 \\
'Karoro' (K) & 0 & 0 & 20 & 0 \\
\hline
\end{tabular}

(SI), 'Te Maori' (NI), 'Matariki' (K)) and lines that were relatively healthy (Figures 1a, b \& c). Two Lsopositive lines, 'Waiporoporo' (NI) and 'Urenika' (K) had the thickest stems in the trial (Figure 1a) at week seven and eight. At week one all lines (except 'Poiwa' (SI)) had fewer than four stems, while by week two stem numbers doubled for most lines (Figure 1b). 'Matariki' (K) did not follow this trend due to delayed emergence into week three and four, where average stem number increased from 0.5 to 5.5 . 'Karoro' (K) at week one had 3.3 stems and reached 10.3 stems at week three, the highest value in this trial. 'Waiporoporo' (NI) and 'Whataroa' (K) were amongst the tallest lines $(88.8 \mathrm{~cm})$ at week eight (Figure 1c). 'Blue Derwent' (SI) and 'Matariki' (K) were the shortest lines in the trial, being at least 10 $\mathrm{cm}$ shorter than the next shortest line ('Te Maori' (SI)) at week eight.

\section{Growth observations}

In general Table 3 shows that the majority of the 17 lines exhibited signs of unhealthy or abnormal growth. An Lso-positive line, 'Waiporoporo'
(NI), was the only line that did not show visible signs of abnormal growth and was the healthiest line in the trial. The Lso-positive 'Waiporoporo' (NI) plant was indistinguishable from the others, suggesting the plant was asymptomatic. Five plants from two lines ('Karoro' (K) and 'Urenika' (K)) were categorised as having HS plants early in the monitoring period; however later observations show that basal stem diameter exceeded $2 \mathrm{~mm}$ for each of these plants. Three WB plants were noted in this trial, one plant each in 'Whataroa' (K), 'Te Maori' (NI) and 'Maori Chief' (NI). Five lines showed varying levels (10-40\%) of leaf cupping at weeks five and six ('Te Maori' (SI), 'Te Maori' (NI), 'Paraketia' (K), 'Maori' $(\mathrm{K})$ and 'Matariki' $(\mathrm{K})$ ). Aerial tubers formed in three lines at week seven and eight; 'Whataroa' (K) and 'Maori Chief' (NI) had one plant each with low numbers of aerial tubers, while four plants in 'Matariki ' $(\mathrm{K})$ had aerial tubers, one of which had a total of 83. Three plants in total died during the 8-week monitoring period, one in 'Maori Chief' (NI) and two in 'Maori' (K). In 
all cases the disease symptoms included in this section were seen in Lso-free (or negative) plants as determined by qPCR diagnostics.

\section{DISCUSSION}

This experiment has confirmed that Lso is present in taewa as qPCR tests detected Lso in three tubers from the North Island. Two of the three Lso-positive tubers emerged and one grew
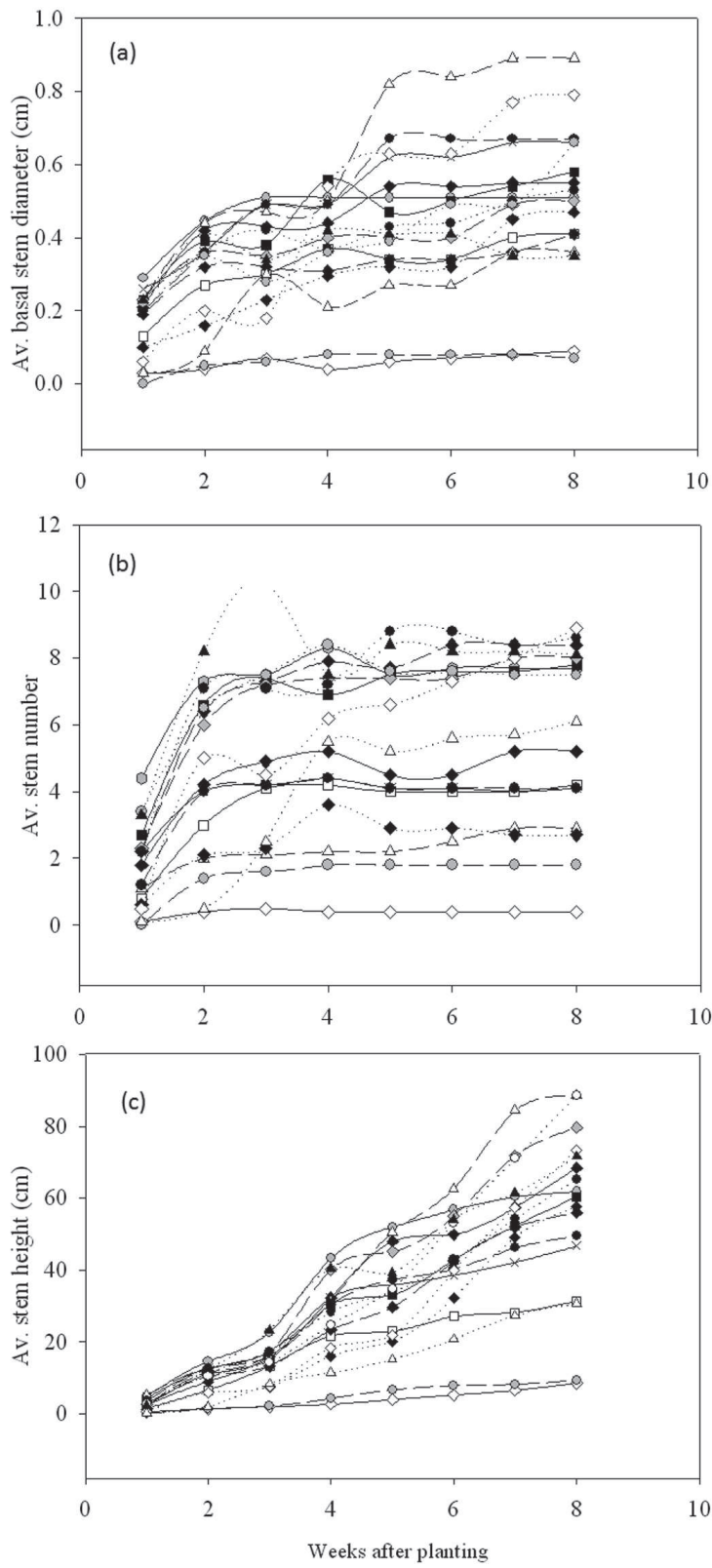

normally thereafter, and one tuber sprouted but did not emerge. Symptoms typical of Lso and other disease symptoms were seen in nearly every other line submitted to this study. Most of the disease symptoms (leaf cupping, witches broom, hair sprout, aerial tubers and plant death) that developed in this trial were seen in purportedly Lso-free lines. The lack of correlation between qPCR results and tuber performance suggests

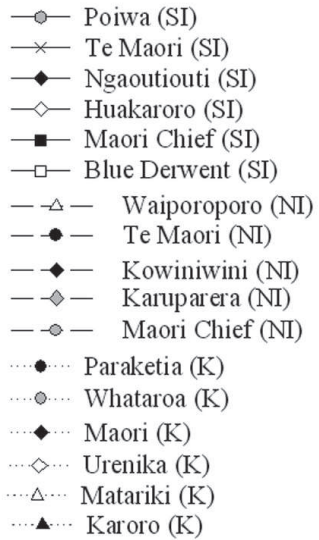

Figure 1 (a) Average basal stem diameter (cm), (b) average stem number and (c) average stem height $(\mathrm{cm})$ per plant for 17 lines of taewa grown in a greenhouse trial. 
Table 3 Tuber emergence, growth status and abnormal growth symptoms recorded over the 8-week monitoring period. Abbreviations used: E = Emergence; $\mathrm{WB}=$ Witches broom; HS = Hair sprout; $\mathrm{AT}=$ Aerial tubers; $\mathrm{R}=$ Rugose (wrinkled or ridged leaves). The Lso positive lines are italicised.

\begin{tabular}{|c|c|c|c|c|c|c|c|c|}
\hline Variety & Week 1 & Week 2 & Week 3 & Week 4 & Week 5 & Week 6 & Week 7 & Week 8 \\
\hline 'Poiwa' (SI) & $100 \% \mathrm{E}$ & $\begin{array}{l}\text { R leaves } \\
\text { all plants }\end{array}$ & $\begin{array}{l}\text { Yellow leaf } \\
\text { mottling }\end{array}$ & & & & & \\
\hline 'Te Maori' (SI) & $100 \% \mathrm{E}$ & & 7 with R leaves & & & 1 wilted & & \\
\hline 'Ngaoutiouti' (SI) & $80 \% \mathrm{E}$ & $10 \% \mathrm{E}$ & $10 \% \mathrm{E}$ & 4 with $\mathrm{R}$ leaves & & & & \\
\hline 'Huakaroro' (SI) & $10 \% \mathrm{E}$ & & & $10 \% \mathrm{E}$ & & & & \\
\hline 'Maori Chief' (SI) & $80 \% \mathrm{E}$ & $20 \% \mathrm{E}$ & & & & & & 1 with 2 AT \\
\hline 'Blue Derwent' (SI) & $50 \% \mathrm{E}$ & $30 \% \mathrm{E}$ & $1 \mathrm{R}$ & $\mathrm{R}$ plant stunted & & & $\begin{array}{l}1 \text { with swollen } \\
\text { internodes }\end{array}$ & \\
\hline 'Waiporoporo' (NI) & $90 \% \mathrm{E}$ & & & & & & & \\
\hline ‘Te Maori’ (NI) & $80 \% \mathrm{E}$ & $20 \% \mathrm{E}$ & 1 plant $\mathrm{R}, 1 \mathrm{WB}$ & $3 \mathrm{R}$ & $4 \mathrm{R}$ & $\begin{array}{l}5 \mathrm{R} \text {, yellow } \\
\text { mottling, }\end{array}$ & & \\
\hline 'Kowiniwini' (NI) & $80 \% \mathrm{E}$ & $20 \% \mathrm{E}$ & $\begin{array}{l}\text { All plants } \\
\text { mottled }\end{array}$ & & & & & \\
\hline 'Karuparera' (NI) & $100 \% \mathrm{E}$ & & & 4 yellowing & & & & \\
\hline 'Maori Chief' (NI) & & $20 \% \mathrm{E}$ & $1 \mathrm{WB}$ & $\begin{array}{l}\text { WB plant small } \\
\text { with R leaves }\end{array}$ & & & WB plant dying & WB plant dead \\
\hline 'Paraketia' (K) & $80 \% \mathrm{E}$ & $20 \% \mathrm{E}$ & & & $\begin{array}{c}3 \text { mottled } \\
\text { plants }\end{array}$ & $\begin{array}{l}3 \text { with upper } \\
\text { leaf cupping }\end{array}$ & & \\
\hline 'Whataroa' (K) & $90 \% \mathrm{E}$ & & $\begin{array}{c}1 \mathrm{WB}, 2 \mathrm{R}, 2 \\
\text { stunted plants }\end{array}$ & $10 \% \mathrm{E}$ & & $3 \mathrm{R}$ & $\begin{array}{l}1 \text { browning, } \\
3 \text { swollen } \\
\text { internodes }\end{array}$ & 1 plant with 3 AT \\
\hline 'Maori' (K) & $50 \% \mathrm{E}$ & & $30 \% \mathrm{E}$ & 1 browning & $\begin{array}{c}2 \\
\text { browning }\end{array}$ & & $2 \mathrm{x}$ dead plants & \\
\hline 'Urenika' $(K)$ & $20 \% \mathrm{E}$ & $40 \% \mathrm{E}$ & $10 \% \mathrm{E}, 2 \mathrm{HS}$ & $20 \% \mathrm{E}$ & & & & \\
\hline 'Matariki' (K) & $30 \% \mathrm{E}$ & $40 \% \mathrm{E}$ & $40 \% \mathrm{E}$ & & & $\begin{array}{c}\text { All plants } \\
\text { mottled }\end{array}$ & 5 leaf cupping & $\begin{array}{c}4 \text { with AT, } 1 \text { with } \\
\text { total of } 83 \text { AT }\end{array}$ \\
\hline 'Karoro' (K) & $100 \% \mathrm{E}$ & & & $3 \mathrm{HS}$ & & & & \\
\hline
\end{tabular}


that either the true incidence of Lso was higher than that detected by the qPCR tests in this trial or that other tuber-borne diseases were responsible for the high incidence of disease symptoms in trial plants. Both these possibilities are discussed below.

Lso is a non-culturable bacterium, so diagnostic tests rely on the detection of Lso genetic material via polymerase chain reaction assays. Many factors can affect the detection of Lso genetic material, including the sensitivity of the test used, Lso titre and Lso distribution within the material tested. Lso distribution is typically uneven within infected plants and the bacterium may be absent or undetectable within some tissues of infected plants (Levy et al. 2011). In this study a single sample (100 $\mathrm{mg}$ ) was taken from each tuber, and it is possible that this level of sampling was insufficient to accurately detect Lso within a tuber. However, Beard et al. (2012) used the same assay with a single sample per tuber and found a positive correlation between Lso titre and tuber symptoms. Beard et al. (2012) found little correlation between percentage of tubers testing positive for Lso and tuber symptoms, but that was because the assay detected low levels of Lso in many tubers that had few or no symptoms. The single round semi-nested assay used in this trial is capable of detecting Lso in very low-titre samples (as few as five copies of the target gene per reaction) (Beard et al. 2012), so it is unlikely results are due to inadequate test sensitivity.

Another possibility is that diseases other than Lso affected the performance of taewa lines in this study. All of the taewa lines used in the study are maintained without using tissue culturing to reduce virus loads in seed tubers, and it is possible that the lines are carrying a considerable viral burden. In 2003 and 2011 a total of five taewa lines from the TWIS/Massey University seed bank were submitted to virus testing. Results from this testing revealed the presence of 10 tuber-borne potato viruses (Potato Viruses A, Y, X, LR, Yc, VS, M, Yo, S and X) in 2003 and four (Potato Viruses X, Y, S and A) in 2011 (J.D Fletcher \& Nick Roskruge, Plant \& Food Research and Massey University, unpublished data).
Plants infected with these viruses often display mosaic patterns on leaves, stunting of the plant, leaf malformations, and tuber malformations (Cornell University 2005). The virus-testing results confirmed the presence of tuber-borne virus diseases in taewa lines which may be the cause of some of the disease symptoms seen in the Lso-free taewa lines.

No Lso was detected in any of the lines sourced from the South Island, which may be related to local TPP population dynamics. On the whole, the Canterbury region experiences lower TPP populations than the North Island monitoring sites, although this is subject to individual monitoring site variation (Berry et al. 2011). The difference in TPP numbers between the two islands may be attributed to many factors, including climate, availability of overwintering host plants and the levels of previous season's infestation. TPP infestations have been recorded at both the TWIS/Massey University and South Island seed source sites, whilst no TPP has been recorded by taewa growers from the Koanga Institute in the Hokianga area (Koanga Gardens 2012), despite Lso being detected in one of their lines. TPP incidence has been reported in tamarillo orchards near Whangarei (Berry et al. 2011) and it is possible that the insect may have reached the Hokianga area although there are no official reports of this.

Maintaining healthy seed tuber stock is an ongoing challenge, especially for taewa growers, as many taewa lines are maintained in home gardens or collections without the use of certified seed. New diseases, like the ZC disease caused by Lso, create additional challenges for potato growers. Although the impact of ZC has been well documented for processing tubers, much less is known about the impact of this disease on seed tuber quality.

This study has provided the first information about the incidence of Lso in taewa lines in New Zealand. The qPCR testing detected Lso in only three of 200 tubers tested. Lso was detected in three seed tubers from three different taewa lines sourced from the North Island: no Lso was detected in any of the South Island lines included in this study. Two of the three Lso-positive seed tubers emerged 
and one continued to show asymptomatic growth. However, many Lso-free tubers failed to sprout or grew abnormally. The results suggest that the taewa lines surveyed may have been infected with tuberborne viruses or diseases, which may have caused the high levels of unhealthy and abnormal growth seen in many of the Lso-free lines. Virus loads and the effects of such viruses on taewa production is an area requiring further study.

\section{ACKNOWLEDGEMENTS}

We thank Russell Genet, Dr Nick Roskruge and Gail Aiken for providing seed tubers for this study and supporting this research.

\section{REFERENCES}

Anderson JAD, Walker GP, Alspach PA, Jeram M, Wright PJ 2012. Assessment of susceptibility to zebra chip and Bactericera cockerelli of selected potato cultivars under different insecticide regimes in New Zealand. American Journal of Potato Research 90: 58-65.

Beard SS, Pitman AR, Kraberger S, Scott IAW 2012. SYBR Green real-time quantitative PCR for the specific detection and quantification of 'Candidatus Liberibacter solanacearum' in field samples from New Zealand. European Journal of Plant Pathology (early electronic view) [DOI 10.1007/s10658-012-0156-5].

Berry N, Jorgensen N, Taylor N 2011. TPP Monitoring Update. Sustainable TPP Management SFF, Objective $4+$ TPP Monitoring Support Project. http://www. potatoesnz.co.nz/users/Image/Downloads/ PDFs/National\%20TPP\%20monitoring_ PFR_2011.pdf (accessed 18 March 2013).

Cameron RJ 1964. Destruction of the indigenous forests for Maori agriculture during the nineteenth century. New Zealand Journal of Forestry 9: 98-109.

Cornell University 2005. Virus problems of potatoes. http://vegetablemdonline.ppath. cornell.edu/NewsArticles/Potato_Virus.htm [accessed 21 March 2013].

Harris GF, Niha PP 1999. Nga Riwai MaoriMaori Potatoes. M. Phil. thesis, Massey University, New Zealand. 65 p.
Harvey RB, Reichenberg A, Lenher B, Haimi PC 1944. Hairsprout of potatoes. Plant Physiology 19: 186-197.

Henne DC, Workneh F, Wen A, PasheJS, Gumstead NC, Rush CM 2010. Characterization and epidemiological significance of potato plants grown from seed tubers affected by zebra chip disease. Plant Disease 94 (6): 659-665.

Koanga Institute 2012. Growing potatoes, tomatoes and peppers with psyllids. http:// www.koanga.org.nz/index.php/blog/cat/ Pest-Control/post/Growing-PotatoesTomatoes-and-Peppers-with-Psyllids (accessed 19 March 2013).

Levy J, Ravindran A, Gross D, Tamborindeguy C, Pierson E 2011. Translocation of 'Candidatus Liberibacter solanacearum', the zebra chip pathogen, in potato and tomato. Phytopathology 101(11): 1285-1291

Nicot N, Hausman JF, Hoffmann L, Evers D 2005. Housekeeping gene selection for real-time RT-PCR normalization in potato during biotic and abiotic stress. Journal of Experimental Botany 56(421): 2907-2914

Pitman AR, Drayton GM, Kraberger SJ, Genet RA, Scott IAW 2011. Tuber transmission of Candidatus Liberibacter solanacearum and its association with zebra chip in potato. European Journal of Plant Pathology 129: 389-398.

Roskruge NR 1999. Taewa Maori, their management, social importance and commercial viability. Research Report Presented in Partial Fulfilment of the Requirements of the Diploma in Maori Resource Development at Massey University, Palmerston North, New Zealand.

Roskruge NR 2007. Hokia ki te whenua. PhD thesis, Massey University, Palmerston North, New Zealand. 263 p.

Scott I, Beard S, Farhat S 2011. MAF SFF TPP Sustainable Management: Milestone 5: Improved Liberibacter Diagnostics. http://www.potatoesnz.co.nz/users/ Image/Downloads/PDFs/Liberibacter\%20 diagnostics_PFR_June\%202011.pdf (accessed 18 March 2013). 